\title{
Phytopathology"
}

\section{Effective Altruism as an Ethical Lens on Research Priorities}

\author{
K. A. Garrett, ${ }^{1,2,3, \dagger}$ R. I. Alcalá-Briseño, ${ }^{1,2,3}$ K. F. Andersen, ${ }^{1,2,3}$ J. Brawner, ${ }^{1}$ R. A. Choudhury, ${ }^{1,2,3}$ E. Delaquis, ${ }^{4}$ \\ J. Fayette, ${ }^{1,2,3}$ R. Poudel, ${ }^{5}$ D. Purves, ${ }^{6}$ J. Rothschild, ${ }^{6}$ I. M. Small, ${ }^{1,7}$ S. Thomas-Sharma, ${ }^{8}$ and Y. Xing ${ }^{1,2,3}$
}

${ }^{1}$ Plant Pathology Department, University of Florida, Gainesville, FL, U.S.A.

${ }^{2}$ Institute for Sustainable Food Systems, University of Florida, Gainesville, FL, U.S.A.

${ }^{3}$ Emerging Pathogens Institute, University of Florida, Gainesville, FL, U.S.A.

${ }^{4}$ International Center for Tropical Agriculture (CIAT), Vientiane, Lao People's Democratic Republic

${ }^{5}$ Genomics and Bioinformatics Research Unit, United States Department of Agriculture-Agricultural Research Service, Gainesville, FL, U.S.A.

${ }^{6}$ Philosophy Department, University of Florida, Gainesville, FL, U.S.A.

${ }^{7}$ North Florida Research \& Education Center, University of Florida, Quincy, FL, U.S.A.

${ }^{8}$ Department of Plant Pathology and Crop Physiology, Louisiana State University Agricultural Center, Baton Rouge, LA, U.S.A.

Accepted for publication 5 December 2019.

\begin{abstract}
Effective altruism is an ethical framework for identifying the greatest potential benefits from investments. Here, we apply effective altruism concepts to maximize research benefits through identification of priority stakeholders, pathosystems, and research questions and technologies. Priority stakeholders for research benefits may include smallholder farmers who have not yet attained the minimal standards set out by the United Nations Sustainable Development Goals; these farmers would often have the most to gain from better crop disease management, if their management problems are tractable. In wildlands, prioritization has been based on the risk of extirpating keystone species, protecting ecosystem services, and preserving wild resources of importance to vulnerable people. Pathosystems may be prioritized based on yield and quality loss, and also factors such as whether other researchers would be unlikely to replace the research efforts if efforts were withdrawn, such as in the case of orphan crops and orphan pathosystems. Research products that help build sustainable and resilient systems can be particularly beneficial. The "value of information" from research can be evaluated in epidemic networks and landscapes, to identify priority locations for both benefits to individuals and to constrain regional epidemics. As decision-making becomes more consolidated and more networked in digital agricultural systems, the range of ethical considerations expands. Low-likelihood but high-damage scenarios such as generalist doomsday pathogens may be research priorities because of the extreme potential cost. Regional microbiomes constitute a commons, and avoiding the "tragedy of the microbiome commons" may depend on shifting research products from "common pool goods" to "public goods" or other categories. We provide suggestions for how individual researchers and funders may make altruism-driven research more effective.
\end{abstract}

Keywords: analytical and theoretical plant pathology, disease control and pest management, ecology and epidemiology, genetics and resistance

${ }^{\dagger}$ Corresponding author: K. A. Garrett; karengarrett@ufl.edu

Current address of R. A. Choudhury: School of Earth, Environmental, and Marine Sciences, University of Texas-Rio Grande Valley, Edinburg, TX, U.S.A.

Funding: We appreciate support by the CGIAR Research Program for Roots, Tubers and Bananas; the CGIAR Research Program on Climate Change and Food Security (CCAFS); United States Department of Agriculture (USDA) National Institute of Food and Agriculture grant 2015-51181-24257; the United States distributed under the CC BY 4.0 International license.
Agency for International Development (USAID) Feed the Future Haiti Appui à la Recherche et au Développement Agricole (AREA) project AID-OAA-A-15-00039; Bill and Melinda Gates Foundation grant OPP1080975; The Ceres Trust; USDA Animal and Plant Health Inspection Service grant 11-8453-1483-CA; U.S. National Science Foundation (NSF) Division of Emerging Frontiers grant EF-0525712 as part of the joint NSF-National Institute of Health Ecology of Infectious Disease program; U.S. NSF Division of Environmental Biology grant DEB-0516046; and the University of Florida.

The contents of this article are the responsibility of the authors and do not necessarily reflect the views of USAID, other funders, or the United States Government.

The author(s) declare no conflict of interest. 
Tout zetwal klere, men tout zetwal pa klere menn jan All stars shine, but not all stars shine the same way - Haitian proverb

\section{EFFECTIVE ALTRUISM AND ITS RELEVANCE TO SETTING RESEARCH PRIORITIES}

Effective altruism is a framework for making altruism more efficient, advocated by some utilitarian consequentialist ethicists (MacAskill 2015; Singer 2015; Unger 1996) and others (Pummer 2016). One motive for the development of effective altruism is the tendency for people to invest philanthropic efforts based on unconsidered impulses so that, for example, people may tend to donate money to a charity with more effective advertising instead of a charity that demonstrably provides more benefits to people. Emerging from philosophical debate on the duty and prioritization for philanthropic giving, effective altruism's concepts do not necessarily require adherence to a specific moral philosophy but, importantly, rely on an evidence-based rationale to prioritize allocation of resources. Ideas in the effective altruism framework may therefore be particularly helpful for evaluating research priorities, where there is often a similar lack of clarity about how to prioritize investments. Of course, part of this lack of clarity is due to the inherent complexity of most important problems-but some share is also due to limited ethical consideration of the positive effects of research and current limitations in the development of the science of science (Fortunato et al. 2018) and policy to support science. Discussions of research ethics often stop short at defining what should not be done: plagiarizing, harassment, falsifying data, taking advantage of research subjects, and so on. Effective altruism offers a perspective on how to use evidence about likely impacts to make research investments as beneficial as possible.

Our objectives in this article are to (i) describe the effective altruism framework and related concepts, as they can be translated into evaluation for research prioritization; (ii) apply these ethical concepts to evaluate prioritization of altruism-driven plant pathology research in terms of pathosystems, stakeholders, research questions, and technologies; and (iii) provide recommendations for individual scientists and policy makers based on these considerations.

For the purposes of discussing effective altruism, we might consider that there are three types of research: (i) curiosity-driven or "blue sky" research, (ii) research to support endeavors in scenarios where primary stakeholders are already successful enough and powerful enough to generate funding (which we term "resourcedriven"), and (iii) research with the goal of providing as substantial a benefit to humans and other species as possible (which we term "altruism-driven") (Fig. 1). These categories for research are not mutually exclusive, and there might be elements of each type in any given research project. Another useful set of metrics for research considers two axes: the degree to which the research addresses fundamental scientific questions and the degree to which it is oriented toward use (Stokes 2011). Pasteur's demonstration of the role of microbes in disease and the potential for vaccination is provided as a prime example of research that was both very successful at contributing to fundamental science and very useful (illustrating that merely categorizing research as basic or applied is overly simplistic). These two sets of categories can be combined as follows (Fig. 1). Curiosity-driven research can be considered successful if it advances fundamental understanding of science. Resource-driven research can be considered successful if it is perceived to be of substantial use by its funders and stakeholders. Altruism-driven research can be considered successful if it produces a substantial benefit to humans or other species; that is, if it is effective altruism. Of course, the categories are not mutually exclusive; increased fundamental understanding may produce a substantial benefit to humans and other species in the long run, if translational science efforts are also in place. Downstream scientific outputs build on a large body of fundamental science, for which a specific end use may or may not have been predicted. The combination of curiosity-driven, resource-driven, and altruismdriven research may create a resilient "research ecosystem". Altruism-driven research deserves more attention, as does associated research to understand how research can be purposefully designed to generate the greatest benefit.

Some may find the term "altruism" misleading in the context of research priorities, because individuals and institutions have complex motivations for embarking on philanthropic projects, including access to resources, personal financial gain, publicity, and elevated standing or prestige in society. The point here is not a lack of benefit for the researcher but to maximize the overall benefits to other people and other species. We acknowledge the peculiarity in our use of the term "altruism-driven research" but the term is appropriate insofar as many of the concepts used to describe this form of research are borrowed directly from the effective altruism framework. Those who are squeamish about the term "altruism" in this context may consider altruism-driven research as "consequence-driven".
Motive of research

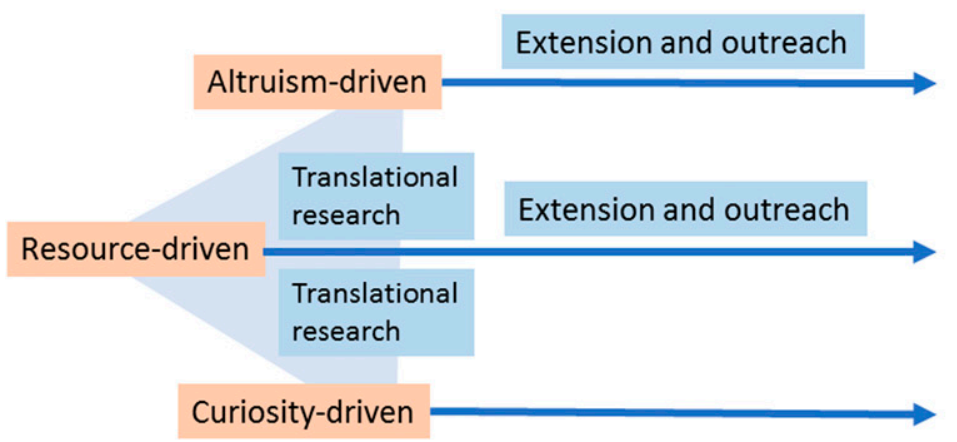

Success

\section{Greatest benefits to humans and other species}

Perceived utility by relatively powerful stakeholders
Contribution to fundamental science

\section{FIGURE 1}

Three categories of research based on motive, and definitions of success associated with them. Translational research can link across these three types. In some cases, altruism-driven research will be research to translate results from curiosity-driven research and resource-driven research to try to achieve the greatest benefits. One point that this article emphasizes is that altruism-driven research may or may not be effective; the effective altruism framework offers concepts to support making altruism-driven research more effective. 


\section{GENERAL CONCEPTS FROM EFFECTIVE ALTRUISM ABOUT PRIORITIZING INVESTMENTS}

Effective altruism frameworks tend to address investments of money and time (e.g., choice of career) but the ideas are relevant for considering research priorities as well. One concept is that investments made where other people are likely to replace withdrawn resources are generally less effective than investments made where alternate resources are unlikely. For example, a person might choose to become a physician to try to have a positive effect on people's lives. If this person works in a prosperous region, they might readily be replaced by another physician of approximately the same abilities (Singer 2015). If the person becomes a physician where there are too few physicians, this would tend to have a greater effect. A second, somewhat related concept is that investments in addressing lowprobability but high-damage scenarios can have particularly important effects. For example, the probability that a giant meteor will strike the Earth in the near future is low but humans and other species dependent on our current environment are likely better off if some people invest effort into formulating response strategies (Singer 2015). A third concept is weighting the benefit provided to people and other species. For example, providing a benefit to people in great need would be more effective than providing the same benefit to people who are already in a good situation. Providing a benefit to more people would likewise be more effective than providing the same benefit to fewer people, assuming equal need. Finally, a fourth and related concept is "tractability": the solvability of the problem addressed by a potential research priority (effectivealtruism.org 2019). For example, the elimination of human aging might have a great positive effect on some people's lives but the problem of aging is highly intractable and, thus, an effective altruism framework might not recommend prioritizing investments in anti-aging research.

Effective altruism has sometimes been a controversial approach for determining resource investment choices. Critics have argued that effective altruism ignores institutional change in favor of individualist philanthropic efforts, and that it overlooks considerations of justice in favor of maximizing general well-being no matter the means (Dietz 2018; Gabriel 2017). These critiques should be kept in mind when adapting the effective altruism framework as a tool for specific application to research prioritization. Plant disease research has often been evaluated with general benefits to society in mind, as in Bentley et al. (1995), and effective altruism offers a complementary ethical framework for evaluating benefits.

\section{HOW RESEARCH IN PLANT PATHOLOGY FURTHERS THE GOALS OF EFFECTIVE ALTRUISM}

Research in plant pathology addresses several major societal problems; principal among them are food security, food safety, and conservation of wildlands and general ecosystem services provided by plants. Although notoriously challenging to calculate (Savary et al. 2012; Wilson 2016), estimates of global food production lost annually in the battle against plant pathogens range from $10 \%$ to 30 to $40 \%$ (Savary et al. 2019; Strange and Scott 2005; Flood 2010). In addition to direct loss through lower crop yield and reduced quality, plant disease causes effects that are likely much greater on food quality and contamination with toxins in food supply chains worldwide (Savary et al. 2012). The management of crop disease adds to the financial and greenhouse gas burdens of agriculture, with additional effects on nontarget species from pesticide use. In the worst cases, such as the Irish Potato Famine, crop diseases have contributed to great human suffering and death through critical food shortages and malnutrition, altering the course of nations (Wilson 2016). Presently, many pathogens remain strongly regionalized, despite the increasingly global distribution and reliance on key staple crops (Bebber et al. 2014); however, pathogen spread continues to accelerate and cause new havoc across the world. For example, Fusarium odoratissimum (or F. oxysporum f. sp. cubense tropical race 4), a major threat to banana and plantain production (Dita et al. 2018), was recently reported in the Americas for the first time (Garcia-Bastidas et al. 2020). Crop pathogens are a particular threat to food security in times and places where people rely on a limited number of key crop species, with few alternative food sources. Pathogens threaten the livelihood of over 1 billion resource-poor smallholder farming households globally. Food safety threats to human health such as aflatoxin in maize (Mutiga et al. 2015) are important, although new biological control options are becoming more widely used (Bandyopadhyay et al. 2016).

Plant pathogens affect wildlands by wiping out plant species such as trees that are key to system productivity (Graziosi et al. 2020). Dramatic examples in the United States include the loss of productive chestnut trees to chestnut blight, the loss of trees in the Lauraceae family to laurel wilt, and the loss of oak and multiple other tree species to Phytophthora ramorum; while, in Australia, P. cinnamomi (Burgess et al. 2017) and Austropuccinia psidii (Berthon et al. 2018) threaten whole plant communities. Recognizing the enormous societal and environmental consequences of plant disease, researchers and funding agencies face an ethical dilemma: how to weigh such consequential outcomes and set research priorities in an increasingly competitive research funding landscape.

\section{SHIFTING FOOD SECURITY PRIORITIES: FROM LIFEBOATS AND TRIAGE TO NUTRITION AND FOOD SOVEREIGNTY}

It's worth taking a moment to contemplate progress in global food security, and the shift in ethical considerations related to food security. Although problems in wildland conservation and the development of global strategies for climate change mitigation and adaptation continue, at least for now, a whole category of ethical considerations for food security is no longer under discussion. Lifeboat and triage ethics for food access were commonly presented in the 1970s (Hardin 1974). The general idea was that the world could not produce enough food for everyone; therefore, ethical consideration was given to who would have to be left out when the insufficient resources were distributed. There would only be so much room on the lifeboat-trying to include additional people would mean everyone would be lost as the lifeboat sank. Since then, increases in production have shifted discourse away from caloric deficiencies to focus more on food security, sustainability, and increasing nutritional quality. Nevertheless, approximately 800 million people still suffer from chronic insufficient food supply (Willett et al. 2019), a number that has increased in recent years, and reductions in agricultural diversity arguably increase food system vulnerability to global pandemics of plant disease. These are strong motivations for prioritizing altruism-driven research programs and using frameworks such as effective altruism to identify the most beneficial investments.

Effective altruism relies on a series of evaluations to identify areas of potential impact. As summarized by Gabriel (2017), these include contextual assessment on the scale of global problems, identification of issues and proven interventions, and whether the problem is neglected to a degree that additional funds are likely to make a difference. We discuss potential rationales for prioritizing research in terms of the traits of stakeholders, pathosystems, and research questions and technologies (Table 1).

\section{PRIORITIZING STAKEHOLDERS}

Rationales for prioritizing stakeholders for research in food security and food safety. The choice of stakeholders to prioritize in research in food security and food safety for effective altruism 
would generally be based on consideration of how many people benefit and how much difference the benefit makes to their lives, often based on socioeconomic analyses (Fig. 2). Resource-driven research would tend to focus on (i) improving and protecting agricultural industries that are already successful enough to provide funding for research through means such as farmer check-off programs, private industry investment, or lobbying of federal research and funding groups, and (ii) current hot topics that are exciting to the scientific community because of their novelty and potential. Altruism-driven research aimed at benefits to humans would tend to focus on problems faced by people who stand to gain the most from better crop disease management. This would often be people who have limited livelihood options outside agriculture and have limited options in terms of crop species that they can profitably produce and, thus, are at risk of regional and household food insecurity. These groups also typically have limited ability to exert influence over allocation of funds from governments or donors. Smallholder farmers in many countries fall into this sector. Criteria for basic living standards such as those in the United Nations (UN) Sustainable Development Goals may be useful (for example, ending hunger, escaping childhood stunting and wasting, access to primary and secondary education, and so on), where communities that have not reached these basic development standards would generally have the greatest benefits from improvements to food security through reduced crop disease. Countries designated by the UN as having least-developed-country status are likely priorities. Improved technologies for women farmers may have important benefits for their family members, as well. Of course, selecting the stakeholders for the most effective research investments may not be so simple when tractability is considered. For example, due to "poverty traps" (Banerjee and Duflo 2011), extremely resourcepoor farmers may not be able to afford or otherwise benefit from improved technologies after project investment ends, whereas moderately resource-poor farmers may be able to use improved technologies and have a greater impact on regional food security. Introducing technologies such that adoption continues after project funding ends is a significant challenge in resource-poor regions.

The CGIAR example. CGIAR (formerly the Consultative Group for International Agricultural Research) was established in 1971 as an example of a generally altruism-driven research organization. CGIAR's research mandate is based on maximizing social well-being through research for development in poverty

TABLE 1

Traits of good candidates for altruism-driven research, in the spirit of classic consequentialism (Mill and Bentham 1987)

\author{
Prioritization of projects with high quantitative impact on human populations \\ - High reduction in yield or quality due to pathogen \\ - Evidence that the disease is likely to become a greater problem under global change, such that managers will have to make a difficult \\ adjustment
}

Prioritization of projects with high qualitative impact on human populations
- High health risk through toxin production
- Threats to landscapes with high social or spiritual value, traditional knowledge, or other intangible cultural heritage
Prioritization of projects with high quantitative impact on nonhuman populations

- Risk of species extinction due to pathogen

Prioritization of projects with high qualitative impact on nonhuman populations

- Loss of ecosystem integrity due to pathogen

Prioritization of projects with high administrative impact (situational factors suggest wide scope of effect, or ease or stability of implementation)

- Likely disease responsiveness to management possibilities, such that research investments are likely to be successful in providing appropriate management options

- Likely sufficient adoption of research results, such that there is benefit to regional management

- Pathogen not present in some countries or continents, such that preventing introduction and establishment has a wide geographic impact

- Other important pathosystems are likely to be similar, so that research spillover will be efficient

- Likely benefits in the short run, through rapid availability of management approach

- Likely long-term benefits that are widespread in terms of numbers of people or geographic reach

Prioritization of projects of important human benefit likely to be overlooked by other avenues of research

- Stakeholders for the pathosystem belong to groups that are important priorities for altruism-driven research but otherwise often underserved

- Stakeholders for the pathosystem have previously been ignored or actively disenfranchised, so that addressing their interests now would be an issue of justice

- The pathosystem is unlikely to be a priority for resource-driven research, so that it could qualify as an "orphan pathosystem"

- The project will result in public goods that are not readily monetized, so that private businesses are unlikely to invest in the research areas

Prioritization of projects unlikely to have adverse effects on other altruism-driven research goals

- Trade-offs are unlikely between benefits for key groups of human stakeholders

- Trade-offs are unlikely in benefits for humans and for nonhuman species

\title{
Prioritization of projects likely to result in future beneficial projects
}

- Providing experimental proof of concept is likely to attract future resources for similar projects

- Projects provide capacity building likely to result in future initiatives by stakeholders who previously lacked the skills to undertake them

a A potential altruism-driven research project could be scored in terms of how well it matches these points. 
reduction, sustainable natural resource management, food security, and human health and nutrition. A recent example is the identification of strategic priorities for cassava research through economic modeling and poverty impact simulations (Alene et al. 2018), an explicit effort to approach research prioritization from a consequentialist perspective. An initial and continuing focus has been on crop breeding, and the success of CGIAR is often evaluated in terms of hectarage planted to cultivars derived from CGIAR genetic material, their increased yield and yield stability, and the resulting return on investment (Raitzer and Kelley 2008; Renkow and Byerlee 2010). The "green revolution" for improved wheat and rice varieties beginning in the 1960s was then driven by two CGIAR centers, the International Maize and Wheat Improvement Center (CIMMYT) and the International Rice Research Institute (IRRI), in partnership with national programs (Byerlee and Dubin 2009). The green revolution saved millions of people from starvation and, although it can be criticized for not benefiting all potential stakeholders, had a massive positive effect through saving lives (Evenson and Gollin 2003). A more recent example of CGIAR efforts to impact key stakeholders is the introduction of $\beta$-carotene biofortified, orange-fleshed sweet potato by HarvestPlus and the International Potato Center (CIP) (Low et al. 2017) to combat childhood vitamin A deficiency in sub-Saharan Africa. Biocontrol for cassava mealybug (Paracoccus manihoti) by an introduced parasitoid wasp (Anagryus lopezi) had a massive effect on food security in 20 cassava-dependent sub-Saharan African countries (Herren et al. 1987), and this biocontrol research had an important spillover effect in Southeast Asia, where the cassava mealybug outbreak in 2008 was quickly controlled using the same technology (Wyckhuys et al. 2018).

CGIAR research has expanded across the decades to include more policy and natural resource management, in "boundary work" aimed at improving agricultural systems through enhanced links between communities of expertise and contributions to decisionmaking and informed negotiation (Clark et al. 2016). In an analysis of 113 studies of research impacts by CGIAR and others for agriculture in sub-Saharan Africa, Pardey et al. (2016) reported an internal rate of return with mean $42 \%$ and median $35 \%$, indicating both the general substantial benefits of the research and also the skewed distribution of the benefits, where the mean return is higher than the median because of the large influence of a limited number of great successes. Such studies are useful for understanding what research has been impactful in the past, to develop frameworks for identifying what types of research are likely to be most useful in the future. "Theories of change" are being developed to guide CGIAR research planning, in part to evaluate impacts of research that are challenging to measure directly (Douthwaite and Hoffecker 2017).

War zones produce particularly vulnerable stakeholders. Wars and natural disasters limit the options of stakeholders, whether stakeholders are farmers managing disease or consumers with limited access to food; therefore, research to offset the damage from war may be particularly valuable. These stakeholders may be priorities from the effective altruism perspective, while their chaotic conditions make improvements challenging and their problems potentially intractable. Considering approaches to ensure food security before the exigencies of war can help to reduce the types of damage people experienced in the following examples. A bumper harvest of potato in Germany during World War I led to an overabundance of potato tubers that were stored in warm and moist basements (Horsfall and Cowling 1978). These tubers were sometimes asymptomatically infected with late blight (caused by Phytophthora infestans), leading to heavily damaging epidemics and famine in the subsequent year. Copper-based pesticides that could have offset the epidemic were unavailable due to wartime restrictions on the materials, and approximately 70,000 civilians starved to death. During World War II, the Bengal region of India was affected by a severe famine caused by a combination of factors, including wartime shortages of rice, rice exports, and brown spot of rice, caused by the fungal pathogen Helminthosporium oryzae (Padmanabhan 1973). Approximately 1.5 million Indians died of starvation during the crisis, which was aggravated by strong rains and disease-conducive conditions. Recent conflicts in Africa likely

\section{Potential prioritization of research by stakeholders, pathosystems, and experimental questions and techniques}

\begin{tabular}{|l|l|}
\hline \multicolumn{2}{|c|}{ Prioritizing stakeholders } \\
\hline Food security \& food safety & Wildlands conservation \\
\hline - People at greatest risk & - Endangered species \\
- People underserved & - Biodiversity hotspots \\
- People who will & - Systems providing \\
$\begin{array}{l}\text { experience the greatest } \\
\text { gain }\end{array}$ & greatest ecosystem \\
- Greatest number & services \\
benefiting & \\
\hline
\end{tabular}

\section{Prioritizing pathosystems}

- Diseases causing the greatest yield loss or quality loss

- Diseases causing the greatest health risks by toxin production

- Systems that would otherwise not receive attention

- Orphan crops and orphan pathosystems

- Geographic locations of greatest importance in epidemic networks

\section{Prioritizing experimental questions and technologies}

Examples, see also Table 1

Avoiding the tragedy of the microbiome commons

- Regional microbiomes can be considered a common pool good like air or water, degraded by individuals who manage plant diseases poorly

- Research providing global public goods can support technology spread and durability (Fig. 5)

Value of information (Vol)

- Providing information that will have a substantial effect to improve key decision-making outcomes

Big ethics for big data

- Addressing costs and benefits of data collection and data availability for the range of stakeholders

- Addressing new ethical questions as networking of digital agriculture advances

Doomsday pathogens

- Addressing low-probability existential risks

FIGURE 2

Factors contributing to prioritization for effective altruism-driven research in plant pathology. 
contributed to the spread of Xanthomonas wilt of banana, moving with migrants attempting to escape the warzone or with soldiers and equipment from affected regions (Ndungo et al. 2008). Introductions of pests and pathogens during war and conflict can devastate food supplies, often affecting civilians most heavily.

War and conflict also threaten germplasm resources needed for disease management. The Syrian Civil War disrupted the International Center for Agricultural Research in the Dry Areas (ICARDA) seed bank in Aleppo, Syria, forcing researchers to rely on duplicate collections at sites in Lebanon and Morocco (Bhattacharya 2016). These germplasm repositories are necessary to maintain drought- and disease-tolerant crops for a region that is being heavily affected by climate change and is the source of many important staple crops, including wheat, barley, and lentil. In Peru, CIP maintains a large catalog of potato varieties from throughout the Andes, the center of diversity for potato. CIP was able to repatriate local tuber varieties after conflicts involving the terrorist group Shining Path led many people to lose their local potato varieties (Huamán and Schmiediche 1999). Root, tuber, and banana crops are important for low-income areas experiencing conflict, because they are less sensitive to harvest timing (compared with crops such as maize) - they can be left in the ground during conflict periods and harvested later, when conditions are safer. Germplasm repositories that store these crops, and research to support their success, are especially critical for regional resilience to famine and climate change (Burns et al. 2010).

Rationales for prioritizing stakeholders or systems for research in wildland conservation. Damage to wildlands is often considered a loss for all people, based on the idea that all humans have wildlands as part of their "natural inheritance". In some cases, specific key stakeholders may also be implicated, such as vulnerable populations who rely on foraging in natural systems to support regional and household food security. Likewise, particular plant species may have important cultural significance for human communities. For example, laurel wilt threatens members of the Lauraceae family (including redbay and swampbay) that are important for cultural celebrations and ceremonies for the Miccosukee and Seminole tribes in Florida (Hughes et al. 2015). Even though these species are unlikely to be driven extinct globally, local extinctions will diminish people's access to them. Although laurel wilt's impact on native forests was severe and is still expanding, it had not been made a high priority for research until the pathogen spread to avocado and the threat of economic damage provided impetus to fund research that spanned production systems and native forest conservation efforts. Another factor for optimization could be the likelihood of success (i.e., tractability) of efforts to protect particular regions. Chestnut blight provides an example of a seemingly intractable problem, extremely difficult to resolve even in a politically stable region.

The choice of stakeholders for altruism-driven research in wildland conservation is complicated by the wide range of potentially convincing ideas about what the goals of conservation should be. Protecting ecosystem services such as the pollinators that impact food production is one human-centered goal for wildlands. The ecosystem services framework provides a means for considering the array of benefits that people receive from ecosystems, wild or agricultural, and interactions that support or counteract benefits (Bennett et al. 2009; Cheatham et al. 2009; Delaquis et al. 2018b; Raudsepp-Hearne et al. 2010). Preventing species extinctions, or at least limiting extinction rates to those observed before widespread human impacts on extinction, is another compelling goal. Conservation biology has addressed optimization in this context by identifying hotspots for biodiversity, so that success in protecting a certain unit of land is likely to protect more species (Myers et al. 2000). Prioritization may also consider the overlap of species' distributions where particularly susceptible species are more likely to spread disease to other hosts at risk of extinction (Berthon et al. 2018). Another factor for optimization could be the likelihood of success in protecting particular regions, where political instability and food insecurity may make conservation less likely.

For research in plant pathology, systems where plant pathogens are having major impacts on wildlands (e.g., as mentioned above, $P$. ramorum and $P$. cinnamomi), often through damage to keystone tree species, are obvious priorities. Tree species provide structural diversity in wildlands and loss of this diversity has significant impacts on other components of forest ecosystems, where loss of forests leads to increased runoff and water turbidity, forest fires, and loss of ecosystem services (Embrey et al. 2012). The loss of tree species is particularly problematic given the time lag between reforestation initiatives and return of a forest canopy and its associated ecosystem services. The long life span of trees makes further demands on research, because effective conservation efforts need to consider both current and future climate scenarios. Tractability of altruism-driven research in wildland conservation is complicated by the effective altruist's commitment to the ethical significance of nonhuman animals (Delon and Purves 2018; Ng 1995, 2016; Sandler 2012; Soulé 1985), whereas concern for the well-being of individual wild animals has previously been assumed to be outside of the scope of conservation biology. A complete picture of altruismdriven research priorities would require an assessment of the comparative ethical importance of the various human interests affected by wildlife conservation, the intrinsic value of native and nonnative species and biodiversity, and the well-being of wild animals.

\section{PRIORITIZING PATHOSYSTEMS}

Rationales for prioritizing pathosystems for food security and food safety. For research addressing food security and food safety, there are several potential approaches for identifying the pathosystems that will provide the biggest payoff from research investment, where optimizing across these criteria is likely to give the best results, where possible (Table 1 ). We can also consider other common points that are issues for consequentialists. A choice between two potential research investments may be better informed if the choice takes into account the potential harm of not pursuing the rejected choice. For example, if the research investment selected provides some benefit but the rejected choice would have resulted in much greater benefit, this is an important consideration.

Yield loss as one important component of prioritization. Yield loss is a common metric for assessing the impact of a disease on a crop, where the highest potential yield is compared with the realized yield under stress conditions (Lobell et al. 2009). Yield loss is generally difficult to assess on a landscape scale, and good global estimates of yield loss in the field are rare (Savary et al. 2019). Although some diseases may cause acute disease loss in some fields, in some seasons, a potentially more useful metric would be regional annual yield loss. Research to provide solutions for diseases that cause high yield loss across a large area or many households may provide the greatest societal benefit. There may be trade-offs, because if yields are "too high" on all farms in a region, there is the potential for a price drop in the market, potentially lowering the profit of individual farmers while benefiting shortterm food security in the region. Addressing yield loss is also a challenge because it may be difficult to combine disease resistance and other desirable quality traits in the same variety. Obtaining better yield loss estimates for diseases, and understanding potential yield-quality trade-offs, would be a priority research pursuit for the effective prioritization of research projects and technologies.

Orphan crops and orphan pathosystems. Orphan crops and orphan pathosystems represent one type of research investment that is less likely to be replaced by other investors. Orphan crops are crops that may be of high importance to particular communities but have not attracted substantial resource-driven research (Naylor 
et al. 2004; Nelson et al. 2004; Varshney et al. 2012). For example, resource-driven research often addresses maize, rice, wheat, soybean, and canola, and model systems such as Arabidopsis and Medicago truncatula. In contrast, orphan crops include teff (the primary grain in Ethiopia), millet, cowpea, taro, and yam. Orphan crops often have important regional economic and cultural value, and may be particularly nutritious and well adapted to specific challenging environments. Orphan crops may also represent a case of "low-hanging fruit", where the same research effort may result in big improvements in crop breeding and disease management compared with crops such as maize and wheat where the "easy" advances may already have been made. For example, lodging problems were addressed in wheat and rice breeding as part of the green revolution but lodging can still be an issue in teff (van Delden et al. 2010). Orphan crops also illustrate the idea that research results may spill over from resource-driven research with the potential to support effective altruism-driven research. Ideally, investment in breeding tools for crops such as maize would produce tools that can be applied, with minor modifications, to orphan crops such as finger millet, investment in M. truncatula benefiting orphan legume crops, and so on (Naylor et al. 2004; Nelson et al. 2004).

Orphan pathosystems include diseases of orphan crops such as quinoa downy mildew and taro leaf blight. Relatively little attention was paid to taro leaf blight until it spread across the Pacific, reportedly contributing to the deaths of $>3,000$ people in a famine in Bougainville, Papua New Guinea, around the end of World War II, causing massive loss of taro diversity in Hawaii and other Pacific islands, and later destroying $99 \%$ of Samoa's primary agricultural export in 1994 (Singh et al. 2012). Diseases of major crops such as rice sheath blight might also be considered orphan pathosystems. Although some orphan pathosystems are caused by pathogens with close relatives from which to draw inference about disease management and biology, others are more unique. Because of the limited cultivated area and the spatial aggregation of orphan crops, diseases may disappear and reemerge later, creating a sputtering epidemic pattern. Many soilborne diseases are understudied due to the difficulty in assessing both cause and effect without destructive sampling. Orphan crops may also have expanded importance if they host diseases shared with other crop species and can act as reservoirs and bridges in the landscape. For example, ulluco (Ullucus tuberosus) would be considered an orphan crop, though it is the second most widely cultivated tuber after potato in the Andean region, and is infected by viruses including ullucus virus $\mathrm{C}$ and ullucus mild mottle virus (Lizárraga et al. 2001). Recently, eight viruses in ulluco grown in England were detected by highthroughput sequencing, demonstrating the potential for pathogens to spread in less-known crops "under the radar" (Fox et al. 2019). Finally, pathogens contributing to postharvest losses are generally understudied despite causing great losses, with too few plant pathologists contributing to better strategies to address them.

Maize lethal necrosis (MLN) is an example of a disease first observed and then effectively managed in one region, only to emerge later in regions with greater food security concerns. MLN was first reported in 1976 in Kansas (Niblett and Claflin 1978), caused by a mixed infection of maize chlorotic mottle virus (MCMV) and potyviruses, and spread to Nebraska, causing yield losses in maize up to $91 \%$ (Niblett and Claflin 1978; Uyemoto 1983). Management strategies were effective in preventing the spread of MLN by managing MCMV (Uyemoto 1983), although MCMV and sugarcane mosaic virus, along with other potyviruses, were still present (Braidwood et al. 2018; Silva-Rosales et al. 2015). MLN was reported again, 35 years later, in Kenya (Wangai et al. 2012), and spread to neighboring countries in sub-Saharan Africa, causing devastating losses to a major staple food in the African continent (Redinbaugh and Stewart 2018). A combination of factors contributed to the reemergence of MLN that involved stakeholders at all levels: the use of maize varieties susceptible to MCMV and sugarcane mosaic virus in East Africa, lack of cultural practices such as crop rotation, and lack of virus-free seed. Research addressing how a disease managed in one region emerges in other regions could motivate improved phytosanitary standards for exporting or importing countries and seed distributors, and programs to increase awareness of potential new outcomes from known diseases.

\section{PRIORITIZING RESEARCH QUESTIONS AND TECHNOLOGIES}

Some research questions and technologies are more likely to benefit key stakeholders and systems for effective altruism (Table 1) than are others, and research can also target how best to reach these key stakeholders.

The value of information as one practical criterion for research prioritization. The concept of the "value of information" refers to the degree to which decision making is improved by availability of a particular unit of information (Canessa et al. 2015; Claxton and Sculpher 2006) such as a new research product meant to benefit key stakeholders. When researchers choose among potential experiments to generate new information to further their goals in effective altruism, they can evaluate the degree to which the experiments are likely to generate information that improves decision-making - such as improving weather-based disease forecasting systems or better characterizing disease resistance profiles for deciding among crop varieties-and evaluate the degree to which these improvements translate into increased yield, profit, sustainability, or other benefits for key stakeholders. The value of information can also be evaluated for other decision makers such as policy makers and donors. For example, a donor might be considering investing in training smallholder farmers who save their own seed in the use of positive selection (i.e., training in how to evaluate disease symptoms and identify plants that look healthy for seed saving) (Gildemacher et al. 2011; Thomas-Sharma et al. 2016). An analysis of the regions where positive selection is likely to have bigger benefits by mapping how well positive selection is likely to work could improve decision-making about geographic priorities for training (Buddenhagen et al. 2018), and could be linked with other effective altruism priorities when integrated with maps of poverty (Bellon et al. 2005). Effective altruism strategies might also include analyses of the value of information that are modified to give higher weight to improved decision-making by higher-priority stakeholders. Integrating analyses of the value of information and geographic risk assessment would help to respond to the charge by critics that effective altruism fails to adequately address policy development due to uncertainty regarding impacts (Gabriel 2017).

The value of information and technologies in networks and landscapes. Impact network analysis is a framework designed to evaluate the value of research products (new information and technologies) in regional systems (Fig. 3) (Garrett 2018; Garrett et al. 2018), an analysis of the regional value of information in the broad sense. It formalizes ideas such as "herd immunity", where effective disease management in enough locations can protect other neighboring locations where management is not implemented-an added preventative dimension which, in some cases, could shift the balance when evaluating effective altruism priorities. This type of system-level analysis can contribute to research prioritization for effective altruism by identifying research products likely to be adopted widely enough to provide substantial regional benefits, as well as strategies to reach key stakeholders within the system. When linked socioeconomic and biophysical networks are understood, we can consider the role of network nodes (in this case, representing individual stakeholders) in terms of the priority they would have in effective altruism strategies and also in terms of their likely roles in epidemic networks-where both of these factors may contribute to the degree of prioritization for stakeholders that produces the 
greatest benefit (Table 1). For example, crop seed systems in many parts of the world do not live up to their potential (Almekinders et al. 2019) and managing inadvertent spread of disease through seed systems may rely on identifying key nodes in seed distribution networks (Andersen et al. 2019, Buddenhagen et al. 2017, Delaquis et al. 2018a). These key nodes might be identified in terms of both how important benefits would be to the particular farmers and how important disease management would be at particular farms for stopping epidemic spread. For researchers and others in agricultural networks, are the ethical responsibilities of individuals a function of their role in the network, so that the Peter Parker Principle would be adapted to, "with great node degree or betweenness centrality comes great responsibility"? In general, understanding the potential for research products to be technologies that scale up to substantial regional benefits is an important research area (Wigboldus et al. 2016).

A new program to redesign agricultural landscapes in Mexico is being implemented to "reactivate" agricultural land in rural areas in 19 states. The plan considers planting approximately 1 million ha in timber, fruit trees, cacao, coffee, vegetables, and maize (https:// www.gob.mx/bienestar/acciones-y-programas/programa-sembrandovida). Landowners with 2.5 ha or more can be considered for this agroforestry project, the goal being to elevate quality of life, generate jobs, and restore deforested areas. However, this increase in cultivated land will convert some isolated regions with low planting rates to medium or high density, modifying the cropland connectivity of Mexico (Margosian et al. 2009; Xing et al. 2017) and potentially increasing the risk of plant pathogen buildup and spread (Fig. 4). Research to identify the potential epidemic role of specific locations can contribute to formulating strategies to protect regional crop health while providing benefits to key stakeholders.

Big ethics for big data and digital agriculture. As "big data" layers become more readily available to support strategies for regional and global disease management, research can also support digital agriculture, leading to greater incorporation of robots and artificial intelligence in farming (Wolfert et al. 2017), with a potential side effect of fewer jobs for farm workers. Data collected across farms can generate better information and predictions for farmers, and can help reduce the ecological footprint of farms through potential reduced pesticide and fossil fuel use. Despite the potential benefits, smart farming and big data have raised several ethical issues about who benefits from research to support digital agriculture, in particular (i) data ownership and access, (ii) distribution of power, (iii) impacts on human life and society, and (iv) fairness and discrimination (van der Burg et al. 2019). The concept of "responsible innovation" was developed to explicitly address the balance between the economic, social, and environmental effects of innovations on multiple stakeholders (Blok and Lemmens 2015; Koops 2015). Responsible innovation is designed to guide innovation toward socially and ethically acceptable ends (Stilgoe et al. 2013), prioritizing the inclusion of rights holders historically marginalized in innovation decision processes (Bronson 2018).

Ownership of data associated with smart farming technologies is not always clearly defined or easily understood. "Advanced tractors" have sensors that can collect data about crop and soil health, while the associated software is trademarked and the resulting data are, in most cases, not openly available beyond those

Socioeconomic network

Exchange of ideas and money

influencing decisions about

management adoption

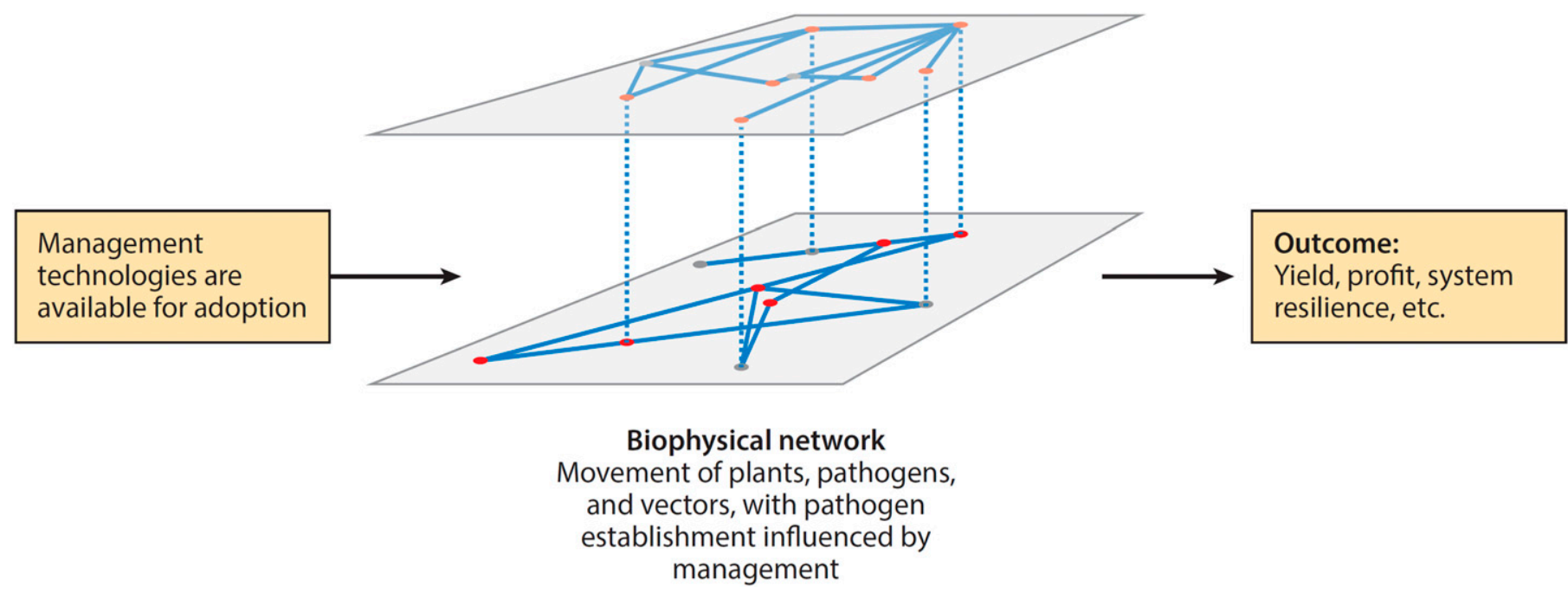

FIGURE 3

Impact network analysis is a framework for evaluating how research products affect regional outcomes. This framework formalizes how the decisions by people represented by nodes in the socioeconomic network (where nodes might be individuals or groups) determine the benefits that a region will experience from technologies. If too few adopt the technology, the region benefits less. Some nodes have a more important role than others in influencing the outcome, because of their position in the socioeconomic network or because of the position of the land they manage in the biophysical network. A dotted line between the network layers indicates that a decision-maker manages the corresponding node (e.g., a farm or farming region, or a biological reserve) in an epidemic network. Evaluating priority stakeholders in this system from the standpoint of effective altruism could be based on (i) the traits of the stakeholders, (ii) the roles of stakeholders in the socioeconomic network, and (iii) the role of the land units the stakeholders manage in the epidemic network. Links in the biophysical network indicate the potential for pathogen spread between land nodes. The set of decisions by land managers creates a disease management landscape. Altruism-driven research would prioritize the development of technologies that should maximize benefits. (Figure reproduced from Garrett et al. (2018) with permission from Annual Reviews.) 
authorized by the owners, such as crop consultants. There may be conflicts of interest if people wish to benefit from large databases and models to interpret the data while keeping their own data to themselves, or if the interests of individual farmers and industries diverge (van der Burg et al. 2019). Groups such as the Open Ag Data Alliance (http://openag.io/) address issues of data ownership and access. The United Nations program for Global Open Data for Agriculture and Nutrition (https://www.godan.info/) advocates for the right to open access to agricultural data as a basic right that could be integrated into the fight against global food insecurity, and CGIAR is moving toward a $100 \%$ open access data model. Truly open access farm data raises issues about farmer privacy and data ownership rights, and whether the benefits of market competition can be maintained. The availability of good models is equally important to make good use of data. To avoid a scenario where development of algorithms only occurs by private corporations, it is imperative for the public sector to participate in algorithm development. For example, corporate systems often provide API access to pull and push data to the system; thus, there is potential for a hybrid public-private partnership toward technology development. Private-sector companies can also contribute to open-source communities while developing their own proprietary systems. Governments have a responsibility to ensure that taxpayer money, invested in the development of technologies including smart farming, contributes to the good of society as a whole (Bronson 2018).

Future automated decision making about crop disease management may depend on weighing the greenhouse gas budget implications of management options (Mahmuti et al. 2009), the nontarget effects of pesticide use, and the likely effects of local decisions on regional epidemics, in addition to local and global agricultural profit, while dealing with the uncertainty associated with each factor. Futurists such as Harari (2018) discuss complex automated decision-making problems. For example, two self-driving cars may be less likely to hit each other because they will be networked together and, thus, aware of the decisions being made by one another. Analogously for land management and disease management, decision making will become more consolidated and

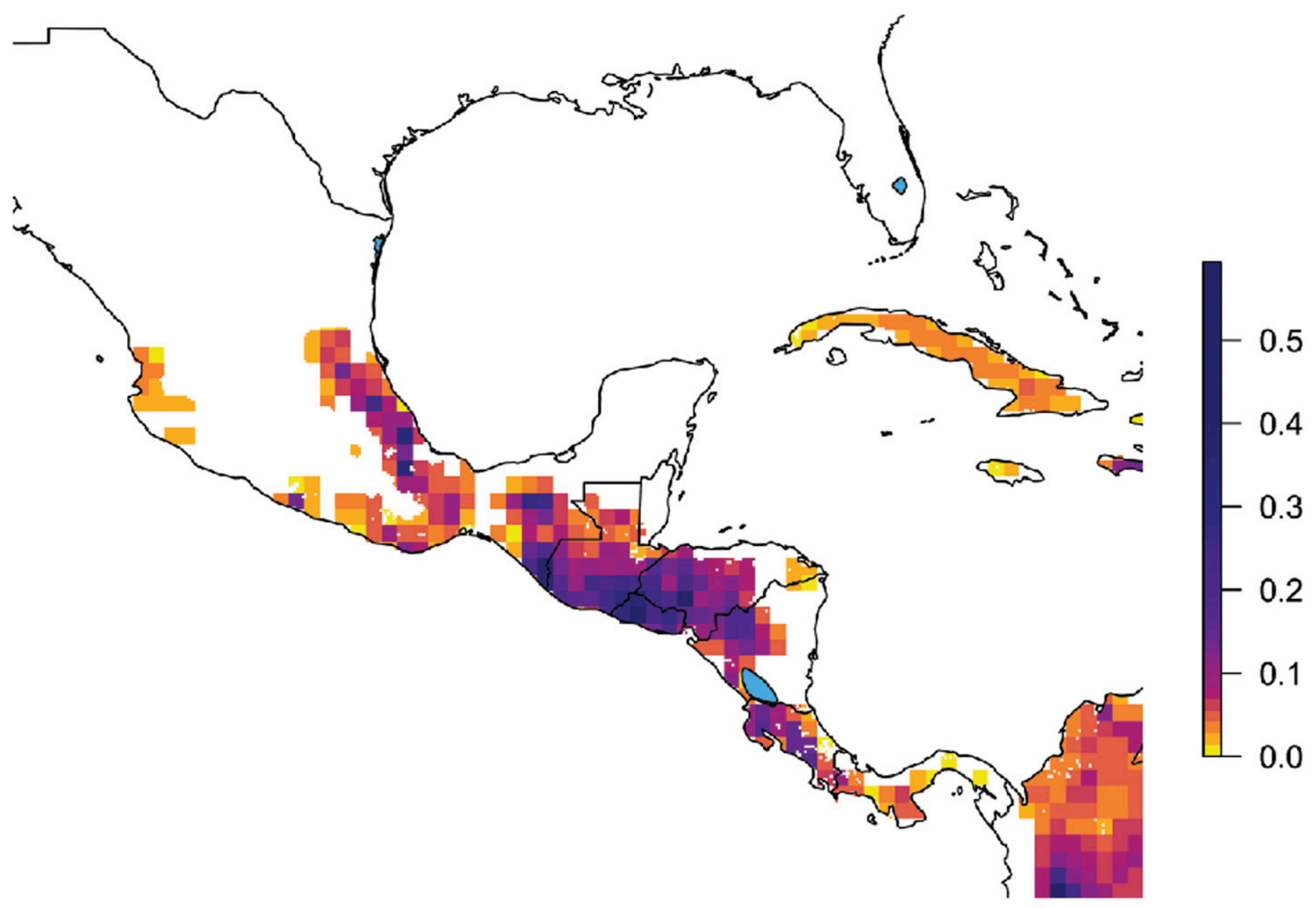

FIGURE 4

Cropland connectivity of coffee production in Mexico. Higher cropland connectivity (darker shading) indicates a likely more important role for a location in potential networks of spread by crop-specific pathogens or other pests through a region. The connectivity of this region is scheduled to increase under the new Mexican plan to boost planting of coffee and other crops. Taking into account cropland connectivity could guide new plantings so as to avoid large increases in connectivity and to keep in mind the risk of spread where connectivity is high. Ethical responsibilities for disease and pest management may be higher where connectivity is greater and, thus, the effects on the common pool regional microbiome are greater. Cropland connectivity risk was evaluated based on two standard global cropland distribution data sets: Monfreda et al. (2008), circa 2000, and the Spatial Production Allocation Model, circa 2010, v1.0 (International Food Policy Research Institute 2019). The analysis of a cropland connectivity risk index (CCRI) followed the methods from Xing et al. (2017), applied to regional coffee production, using an uncertainty quantification to evaluate the mean across negative exponential and inverse power law dispersal parameters. The CCRI is a weighted mean of betweenness centrality, node strength, the sum of nearest neighbors' node degrees, and eigenvector centrality (Xing et al. 2017). 
more networked; therefore, less-networked land managers may make decisions in greater isolation. Are the people developing digital agriculture algorithms responsible for their accuracy, or for the cumulative effects of the decisions based on them? And what types of existential threats could occur from globally networked bad decisions about agricultural management? Linked agricultural systems will also need to be protected from cyberattacks such as ransomware attacks in the same way as national power systems and financial systems.

Dual-use technology and bioterrorism risks. "Dual-use" research results and technologies are those that may offer societal benefits but also have the potential to support goals destructive to society, such as bioterrorism. For consequentialists, avoiding potential harm may be more important than seeking potential benefit (Shiffrin 1999). Most research in plant pathology might be considered to have some dual-use risk, if only because it might (i) contribute to the use of existing pathogens as weapons and (ii) ultimately support applications of synthetic biology to generate more harmful pathogens. Fortunately, intentional dissemination of plant pathogens for destructive purposes has been rare compared with other terrorist activities (Suffert et al. 2009), although both the United States and Soviet forces stockpiled spores of Puccinia graminis, the causal agent of wheat stem rust, during the cold war (Mackenzie 2007), and there is an example of likely intentional introduction of the cacao witch's broom pathogen (Crinipellis perniciosa) to the southern Brazilian region of Bahia (Caldas and Perz 2013). There is debate about whether the design of insects to deploy genetic information to plants in a virus-like form, as a potential means for spreading positive traits such as disease resistance (Bextine 2018a), is a risk for development of biological weapons-where, even though the technology is not being used as such by the United States, it could motivate other countries to join the race to develop insect deployment of viruses (Bextine 2018b; Reeves et al. 2018). In addition to state actors who may use pathogens and vectors destructively, upscaling of the availability of synthetic biology techniques may result in individuals or groups attempting to produce more destructive pathogens, as well as unanticipated problems analogous to unforeseen problems with upscaled social media. For example, the ease and prevalence of futures and commodity trading for crop products provides one possibility for abuse of pathogen research for personal gain.

Doomsday pathogens: low likelihood but high damage scenarios. One effective altruism strategy for providing important benefits is to address disastrous scenarios that are unlikely and, thus, might be overlooked by other researchers. One possibility is a plant pathogen that creates a "doomsday" scenario, such as an aggressive generalist pathogen of the Poaceae decimating large swaths of staple crops and disrupting regional or global food security, resulting in widespread famine and armed conflict (Horsfall and Cowling 1978; Mackenzie 2007; Ndungo et al. 2008). Such a "black swan" event could impose major stress on global food security because few institutions are prepared to quickly manage such a situation (Ploetz et al. 2013). A doomsday-scale scenario could result from a major shift in one or more components of the disease triangle. The recent emergence of the $\mathrm{Ug} 99$ wheat stem rust variant was largely due to a pathogen genotype that was able to overcome the durable SR31 resistance allele (Mackenzie 2007). As industrial agriculture becomes more consolidated, crop homogenization is an increasingly important risk factor. The switch from self-pollinated to hybrid corn led to a unique susceptibility in the Texas cytoplasm $\mathrm{T}$ maize variants in the early 1970s, leading to a massive and seemingly unpredictable U.S. epidemic of southern corn leaf blight (Levings 1990), although fortunately in a context where it had limited effect on food security. Climate change will likely alter suitability for many diseases, where little-understood thresholds for disease effects in some regions may result in surprising magnitudes of effects (Garrett et al. 2011). Mitigating these risks with global seed banks like the Svalbard seed vault may help to moderate disease risk, although these seed banks themselves are not invulnerable to risk (Carrington 2017) and are capable of maintaining only a small fraction of crop diversity, and their use implies a substantial lag time before seed can become widely available for planting. In general, it would be useful for researchers to invest some time in evaluating the worst-case scenarios for the systems they work with in a global context, and the response that would be necessary to deal with these scenarios, even when such scenarios are unlikely. It would be valuable for this to become a standard practice in formats analogous to pest risk assessments, potentially organized by a risk assessment network in a future global surveillance system (Carvajal-Yepes et al. 2019).

Designing sustainable and resilient systems. Resilience and sustainability are key for any system to achieve long-term benefits from interventions. Resilience is a system's ability to return to function after experiencing a stressor, where stressors might be predictable or unforeseen (Oliver et al. 2015; Walker et al. 2004). Sustainability is a system's ability to continue to provide functions or productivity into the future, without hampering the ability of future generations to meet their needs (Chapin et al. 2010). Research on increasing resilience and sustainability of agricultural systems can use concepts from effective altruism to orient the assessment of risks and benefits to key stakeholders (Table 1) related to relevant current or potential threats. New diseases, reemergence of known diseases, unpredictable climate consequences, and wars and conflicts represent some of the potential shocks that jeopardize food security. Curiosity-driven and resource-driven research may generally help to boost system resilience and sustainability by offering more options, so that systems are more likely to meet future demands for food and feed. Preparedness can be via global research initiatives such as the Borlaug global rust initiative to counterbalance the effect of new genotypes of wheat stem rust such as $\mathrm{Ug} 99$ (Singh et al. 2015) and a proposed global surveillance system to link efforts for addressing new diseases (Carvajal-Yepes et al. 2019). Svalbard seed vault resources (the seed of an ancient Syrian grass, Aegilops tauschii) were used to identify candidate genes for resistance to the devastating pest Hessian fly (Miranda et al. 2010; Singh et al. 2019), which caused an annual yield loss of 5 to $10 \%$ in U.S.-grown wheat (Schmid et al. 2018) and threatens wheat production worldwide.

Increases in productivity can also reduce land pressure for competing uses (such as wildland conservation). Increases in cereal productivity during the green revolution are estimated to have prevented 2 million ha of deforestation and 16 to 25 million ha of conversion of pasture, which would have otherwise been needed to obtain 2004 cereal production levels with pre-green-revolution yields (Stevenson et al. 2013). Estimates of land sparing due to development require a number of assumptions (Byerlee et al. 2014) but it must be true that desperation for food production was reduced.

Difficult trade-offs and wicked problems. Success in identifying key systems and scientific questions to benefit key stakeholders depends on understanding what information and technologies will provide substantial benefits. In most systems of real importance to the well-being of humans and other species, enduring problems tend to be "wicked problems", meaning those with no single solution for all stakeholders and, thus, requiring the weighing of complex tradeoffs (as opposed to "tame" problems, for which a single optimal solution can be found) (Rittel and Webber 1973). Reductionist tame questions such as questions about the effect of a gene, the genome sequence of a pathogen, the causal agent of a disease, the model describing pathogen dispersal probabilities across space, or the effect of weather on disease risk are often successfully addressed by plant pathologists. In contrast, wicked problems are difficult to define, situationally unique, and often related to trade-offs in public policy. Issues that might be considered wicked problems, or at least difficult trade-offs, related to plant disease management include the following. (i) New forms 
of crop disease resistance may increase yields for farmers but increased crop availability may reduce market prices, such that farmers experience reduced profits-or the technologies might greatly benefit medium-resource farmers but cause low-resource growers to go out of business. (ii) New, productive genotypes or crop species that people hoped would contribute to reduced pressure for conversion of wildlands to agriculture may be so profitable that they motivate increased land conversion. (iii) Crop subsidies intended to support farmers afflicted by a plant disease may provide incentives to continue unsustainable production methods, prolonging and exacerbating the problem by incentivizing avoidance of the systemic issues leading to the instability. (iv) Successful new disease-resistant cultivars may threaten crop biodiversity as they displace traditional varieties, and they may produce strong selection pressures for pathogen evolution when they are planted across wide regions (Helfer 2014). Wicked problems are a strong motivation for research in plant pathology to link with other disciplines such as socioeconomics to increase the likelihood of substantial benefits.

Global public goods and avoiding the tragedy of the microbiome commons. When research products are "common pool goods", their benefits will often be less sustainable (Fig. 5). The idea of the tragedy of the commons was introduced in the context of common grazing lands, where shepherds are individually motivated to graze as much as possible but cumulatively degrade the productivity of the grazing lands (Hardin 1968). The microbiome of a geographic region, and especially regional pathogen meta-communities, can also be thought of as common pool goods, along with air and water (Fig. 5). An individual land manager who chooses not to invest in disease management can reduce the quality of the regional microbiome for all land managers. Research products that depend on lower regional inoculum loads for successful implementation, such as some variety mixtures and resistance genes that only reduce inoculum production, may become useless in the context of poor management by neighbors. Similarly, management decisions of a small number of individuals that select for antibiotic resistance will also compromise the utility or availability of antibiotics/pesticides. Research may be more beneficial in many ways if it results in global public goods such as public data and models for disease management and publicly available durable disease resistance genes (Fig. 5). In many cases, however, durable resistance is not available and disease management must rely on cooperation, making people vulnerable to the decisions of others but also potentially building cooperation (social capital) that would be useful in other ways. Financial incentives for the distribution of "exclusive" technologies can support their spread, just as bottled soft drinks are available in some areas of the world where clean water is not. A combination of public and private enterprise may be most sustainable for systems such as breeding for resistance (Garrett et al. 2017) or the development of digital agriculture technologies and, more generally, where systems may benefit from both functional diversity and redundancy (Biggs et al. 2012).

\section{RECOMMENDATIONS AND CONCLUSIONS}

Options for individual researchers. In times of funding challenges, it would usually only be practical for individual researchers to invest in altruism-driven research that is simultaneously resource-driven or

\begin{tabular}{|c|c|c|c|c|c|}
\hline \multirow[t]{2}{*}{ Consumption } & \multicolumn{5}{|c|}{ Access } \\
\hline & \multicolumn{3}{|c|}{ Exclusive } & \multicolumn{2}{|c|}{ Non-exclusive } \\
\hline \multirow{3}{*}{ Rival } & \multicolumn{3}{|c|}{ Private goods: e. g., food } & \multicolumn{2}{|c|}{$\begin{array}{l}\text { Common pool goods: e. g., air, water } \\
\text { Regional microbiome } \\
\text { Regional pathogen meta- } \\
\text { communities }\end{array}$} \\
\hline & \multirow{2}{*}{\multicolumn{2}{|c|}{$\begin{array}{l}\text { Pesticides } \\
\text { vulnerable } \\
\text { to antibiotic } \\
\text { resistance }\end{array}$}} & $\begin{array}{l}\text { Formal seed } \\
\text { systems }\end{array}$ & $\begin{array}{l}\text { Informal seed } \\
\text { systems }\end{array}$ & \\
\hline & & & $\begin{array}{l}\text { Private non- } \\
\text { durable resistance } \\
\text { genes }\end{array}$ & $\begin{array}{l}\text { Public non-durable } \\
\text { resistance genes }\end{array}$ & \\
\hline Non-rival & $\begin{array}{l}\text { Club/toll } \\
\text { goods: } \\
\text { e. g., private } \\
\text { schools }\end{array}$ & $\begin{array}{l}\text { Pesticides } \\
\text { not } \\
\text { vulnerable } \\
\text { to antibiotic } \\
\text { resistance }\end{array}$ & $\begin{array}{l}\text { Private durable } \\
\text { resistance genes } \\
\text { Private data and } \\
\text { models for disease } \\
\text { management }\end{array}$ & $\begin{array}{l}\text { Public durable } \\
\text { resistance genes } \\
\text { Public data and } \\
\text { models for disease } \\
\text { management }\end{array}$ & $\begin{array}{l}\text { Public } \\
\text { goods: e. g., } \\
\text { sunshine }\end{array}$ \\
\hline
\end{tabular}

\section{FIGURE 5}

Goods such as research products can be classified as private, common pool, club (toll), or public, depending on whether the goods can be used up or degraded (rival as opposed to nonrival) and whether access to the goods is controlled (exclusive as opposed to nonexclusive) (CGIAR Science Council 2006). A problematic combination is the "commons," the common pool goods that are nonexclusive, so that all have access, at the same time that they can be used up or reduced in quality. Regional microbiomes and regional pathogen metacommunities can be thought of as common pool goods, just like the example of air and water, because they also are open to the influence of all people who have access to them and who may degrade them through poor plant disease management choices. We also present a categorization for several important types of plant pathology research products. Research targeted to developing more durable resistance genes, and pesticides less vulnerable to antibiotic resistance, move these products toward the nonrival category, and make systems more likely to be resilient. Seed systems, resistance genes, and data and models may all be exclusive or nonexclusive_-if they are common pool goods, they are vulnerable; whereas, as public goods, they can provide benefits more sustainably. 
has prospects for transitioning to resource-driven research. Of course, some funders have priorities that overlap substantially with priorities for altruism-driven research. Even when researchers generally address resource- or curiosity-driven agendas, they could add a component of altruism-driven research, and use an effective altruism framework to guide prioritization. For example, it is common for plant pathologists in the United States to have responsibility for a major industrial crop and its needs in a particular state. These researchers might dedicate the majority of their time to that topic but could make a point of dedicating some part of their time to pathology needs for stakeholders who would be a high priority in an effective altruism framework. These research efforts might include (i) partnerships with pathologists in countries that have more limited research resources but are well positioned to benefit priority stakeholders, providing training and mentoring when useful, working to improve capacity and knowledge about funding opportunities, and developing professional networks and global communities of practice; (ii) including plant genotypes or pathogen isolates from priority regions in studies when useful; (iii) developing strategies to facilitate research spillover to other plant species, especially orphan crops or threatened wild species, and developing low-cost versions of research and management systems; (iv) extending epidemiological risk assessments beyond the initial project focus, when data are available, and evaluating low-probability worst-case global scenarios; and (v) using reproducible research approaches, with data and code publicly available, in support of the open plant pathology community (https://openplantpathology.org/). Training components of research agendas could provide open-access materials online and engage global plant pathologists in helping to make the materials relevant globally, supported by research about how to make e-learning more impactful.

Options for policymakers and funders. It can be challenging for individual researchers to carve out the time to add obligations, even when they are personally motivated to use ideas from effective altruism to guide some of their research priorities. Altruism-driven research will be more practical if policy makers and funders have a general policy of supporting and rewarding researchers' altruismdriven research time investments. Policy makers could consider supporting registration of projects designed to contribute to reaching the UN sustainable development goals (Capua and Giovannini 2019), and designing and implementing an ontology for project traits that support effective altruism. For funders who already emphasize benefits to humanity and wildlands, effective altruism provides a framework for better prioritizing research (Table 1). For funders who emphasize benefits to particular industries, a component of altruismdriven research could be a standard element, with researchers asked to explicitly consider how new technologies are likely to have effects beyond direct stakeholders; likewise, underutilized computational and data storage resources could be made available to altruism-driven research efforts, and free licensing for access to intellectual property or paid software. For funders who emphasize curiosity-driven research, statements about the broader impacts of studies could be held to a higher standard in the review process. In the same way that curiosity-driven research may provide practical benefits in the long run, research to address effective altruism priorities may inspire fundamental scientific progress in new multidisciplinary and nonreductionist areas, including the science of science policy, increasing clarity about how to create the most substantial benefits from research and strengthening systems.

Conclusions. Effective altruism can be a useful framework for developing research priorities but ethical frameworks remain underused by most researchers and funders. Of course, there is often a high level of uncertainty about the downstream effects of research efforts, particularly in curiosity-driven research. It is precisely for this reason that effective altruism and its evidencebased ethical system provides an important structure for supporting prioritization exercises. For altruism-driven research, otherwise appealing projects may prove to have limited effectiveness because of misunderstood socioeconomic incentives and constraints, or even misunderstood biology. However, it will often be possible to roughly rank the likely benefits of different candidates for altruism-driven research efforts through the lens of effective altruism, considering criteria such as those in Table 1 . This concept is analogous to effective altruism applications in philanthropy, such as the ranking aggregation website GiveWell (https://www.givewell.org/), designed for choosing among charities based on effective altruism concepts. Using effective altruism ideas to rank prospective research foci encourages a widening of perspective and realistic evaluation of potential impacts, and may be particularly successful when participatory evaluations with stakeholders ensure needed perspective. Supporting the science of science policy in research to better understand outcomes for human well-being and wildland conservation can have multiplying effects by helping researchers to make their altruismdriven research efforts more effective, potentially beyond the usual scope of their activities. An important research focus for the science of science policy will be to better understand how resource-driven research may interact with, conflict with, or serve altruism-driven research, particularly in the context of effective altruism.

There are many more potential strategies for boosting the effectiveness of altruism-driven research beyond those proposed here for individual researchers and for policymakers and donors. We propose to support ideas from the plant pathology community in a living document, with more details available at https:// www.garrettlab.com/effective-altruism/.

\section{ACKNOWLEDGMENTS}

We thank Phytopathology reviewers for their comments and S. Gold for editorial input.

\section{LITERATURE CITED}

Alene, A. D., Abdoulaye, T., Rusike, J., Labarta, R., Creamer, B., Del Rio, M., Ceballos, H., and Becerra, L. A. 2018. Identifying crop research priorities based on potential economic and poverty reduction impacts: The case of cassava in Africa, Asia, and Latin America. PLOS One 13:e0201803.

Almekinders, C. J., Walsh, S., Jacobsen, K. S., Andrade-Piedra, J. L., McEwan, M. A., de Haan, S., Kumar, L., and Staver, C. 2019. Why interventions in the seed systems of roots, tubers and bananas crops do not reach their full potential. Food Secur. 11:23-42.

Andersen, K. F., Buddenhagen, C. E., Rachkara, P., Gibson, R., Kalule, S., Phillips, D., and Garrett, K. A. 2019. Modeling epidemics in seed systems and landscapes to guide management strategies: The case of sweetpotato in Northern Uganda. Phytopathology 109:1519-1532.

Bandyopadhyay, R., Ortega-Beltran, A., Akande, A., Mutegi, C., Atehnkeng, J., Kaptoge, L., Senghor, A. L., Adhikari, B. N., and Cotty, P. J. 2016. Biological control of aflatoxins in Africa: Current status and potential challenges in the face of climate change. World Mycotoxin J. 9:771-789.

Banerjee, A. V., and Duflo, E. 2011. Poor Economics: A Radical Rethinking of the Way to Fight Global Poverty. PublicAffairs, New York.

Bebber, D. P., Holmes, T., and Gurr, S. J. 2014. The global spread of crop pests and pathogens. Glob. Ecol. Biogeogr. 23:1398-1407.

Bellon, M. R., Hodson, D., Bergvinson, D., Beck, D., Martinez-Romero, E., and Montoya, Y. 2005. Targeting agricultural research to benefit poor farmers: Relating poverty mapping to maize environments in Mexico. Food Policy 30:476-492.

Bennett, E. M., Peterson, G. D., and Gordon, L. J. 2009. Understanding relationships among multiple ecosystem services. Ecol. Lett. 12:1394-1404.

Bentley, J. W., Castaño-Zapata, J., and Andrews, K. L. 1995. World integrated pathogen and pest management and sustainable agriculture in the developing world. Adv. Plant Pathol. 11:249-276.

Berthon, K., Esperon-Rodriguez, M., Beaumont, L. J., Carnegie, A. J., and Leishman, M. R. 2018. Assessment and prioritisation of plant species at risk from myrtle rust (Austropuccinia psidii) under current and future climates in Australia. Biol. Conserv. 218:154-162.

Bextine, B. 2018a. Insect Allies. Defense Advanced Research Projects Agency. https://www.darpa.mil/program/insect-allies

Bextine, B. 2018b. Statement from Dr. Blake Bextine, DARPA Program Manager for Insect Allies. https://www.darpa.mil/attachments/DARPA\% 20Response $\% 20$ to $\% 20$ Science $\% 20$ Opinion $\% 20$ Piece $\% 20-\% 20$ Oct $\%$ 204\% 202018.pdf 
Bhattacharya, S. 2016. Syrian seed bank gets new home away from war. NATNEWS 538:16

Biggs, R., Schlüter, M., Biggs, D., Bohensky, E. L., BurnSilver, S., Cundill, G., Dakos, V., Daw, T. M., Evans, L. S., Kotschy, K., Leitch, A. M., Meek, C., Quinlan, A., Raudsepp-Hearne, C., Robards, M. D., Schoon, M. L., Schultz, L., and West, P. C. 2012. Toward principles for enhancing the resilience of ecosystem services. Annu. Rev. Environ. Resour. 37:421-448.

Blok, V., and Lemmens, P. 2015. The emerging concept of responsible innovation. Three reasons why it is questionable and calls for a radical transformation of the concept of innovation. Pages 19-35 in: Responsible Innovation 2: Concepts, Approaches, and Applications. B.-J. Koops, I. Oosterlaken, H. Romijn, T. Swierstra, and J. van den Hoven, eds. Springer International Publishing, Cham, Switzerland.

Braidwood, L., Quito-Avila, D. F., Cabanas, D., Bressan, A., Wangai, A., and Baulcombe, D. C. 2018. Maize chlorotic mottle virus exhibits low divergence between differentiated regional sub-populations. Sci. Rep. 8:1173.

Bronson, K. 2018. Smart farming: Including rights holders for responsible agricultural innovation. Technol. Innovation Manage. Rev. 8:7-14.

Buddenhagen, C. E., Andrade Piedra, J., Forbes, G. A., Kromann, P., Navarrete, I., Thomas-Sharma, S., Xing, Y., and Garrett, K. A. 2018. Management performance mapping: The value of information for regional prioritization of disease management interventions. bioRxiv doi:10.1101/380352

Buddenhagen, C. E., Hernandez Nopsa, J. F., Andersen, K. F., Andrade-Piedra, J., Forbes, G. A., Kromann, P., Thomas-Sharma, S., Useche, P., and Garrett, K. A. 2017. Epidemic network analysis for mitigation of invasive pathogens in seed systems: Potato in Ecuador. Phytopathology 107:1209-1218.

Burgess, T. I., Scott, J. K., Mcdougall, K. L., Stukely, M. J. C., Crane, C., Dunstan, W. A., Brigg, F., Andjic, V., White, D., Rudman, T., Arentz, F., Ota, N., and Hardy, G. E. S. J. 2017. Current and projected global distribution of Phytophthora cinnamomi, one of the world's worst plant pathogens. Glob. Change Biol. 23:1661-1674.

Burns, A., Gleadow, R., Cliff, J., Zacarias, A., and Cavagnaro, T. 2010. Cassava: The drought, war and famine crop in a changing world. Sustainability 2:3572-3607.

Byerlee, D., and Dubin, H. 2009. Crop improvement in the CGIAR as a global success story of open access and international collaboration. Int. J. Commons 4:452-480.

Byerlee, D., Stevenson, J., and Villoria, N. 2014. Does intensification slow crop land expansion or encourage deforestation? Glob. Food Secur. 3: 92-98.

Caldas, M. M., and Perz, S. 2013. Agro-terrorism? The causes and consequences of the appearance of witch's broom disease in cocoa plantations of southern Bahia, Brazil. Geoforum 47:147-157.

Canessa, S., Guillera-Arroita, G., Lahoz-Monfort, J. J., Southwell, D. M., Armstrong, D. P., Chadès, I., Lacy, R. C., and Converse, S. J. 2015. When do we need more data? A primer on calculating the value of information for applied ecologists. Methods Ecol. Evol. 6:1219-1228.

Capua, I., and Giovannini, E. 2019. Coding system to track research progress towards SDGs. Nature 572:178.

Carrington, D. 2017. Arctic stronghold of world's seeds flooded after permafrost melts. The Guardian. https://www.theguardian.com/environment/ 2017/may/19/arctic-stronghold-of-worlds-seeds-flooded-after-permafrost-melts

Carvajal-Yepes, M., Cardwell, K., Nelson, A., Garrett, K. A., Giovani, B., Saunders, D., Kamoun, S., Legg, J., Verdier, V., Lessel, J., Neher, R. A., Day, R., Pardey, P., Gullino, M. L., Records, A. R., Bextine, B., Leach, J. E., Staiger, S., and Tohme, J. 2019. A global surveillance system for crop diseases. Science 364:1237-1239.

CGIAR Science Council. 2006. Positioning the CGIAR in the Research for Development Continuum. CGIAR Science Council Secretariat, Rome, Italy.

Chapin, F. S., Carpenter, S. R., Kofinas, G. P., Folke, C., Abel, N., Clark, W. C., Olsson, P., Smith, D. M. S., Walker, B., Young, O. R., Berkes, F., Biggs, R., Grove, J. M., Naylor, R. L., Pinkerton, E., Steffen, W., and Swanson, F. J. 2010. Ecosystem stewardship: Sustainability strategies for a rapidly changing planet. Trends Ecol. Evol. 25:241-249.

Cheatham, M. R., Rouse, M. N., Esker, P. D., Ignacio, S., Pradel, W., Raymundo, R., Sparks, A. H., Forbes, G. A., Gordon, T. R., and Garrett, K. A. 2009. Beyond yield: Plant disease in the context of ecosystem services. Phytopathology 99:1228-1236.

Clark, W. C., Tomich, T. P., van Noordwijk, M., Guston, D., Catacutan, D., Dickson, N. M., and McNie, E. 2016. Boundary work for sustainable development: Natural resource management at the Consultative Group on International Agricultural Research (CGIAR). Proc. Natl. Acad. Sci. U.S.A. 113:4615-4622.

Claxton, K. P., and Sculpher, M. J. 2006. Using value of information analysis to prioritise health research-Some lessons from recent UK experience. Pharmacoeconomics 24:1055-1068.

Delaquis, E., Andersen, K. F., Minato, N., Cu, T. T. L., Karssenberg, M. E., Sok, S., Wyckhuys, K. A. G., Newby, J. C., Burra, D. D., Srean, P., Phirun,
I., Le, N. D., Pham, N. T., Garrett, K. A., Almekinders, C. J. M., Struik, P. C., and de Haan, S. 2018a. Raising the stakes: Cassava seed networks at multiple scales in Cambodia and Vietnam. Front. Sustain. Food Syst. 2:73.

Delaquis, E., de Haan, S., and Wyckhuys, K. A. 2018b. On-farm diversity offsets environmental pressures in tropical agro-ecosystems: A synthetic review for cassava-based systems. Agric. Ecosyst. Environ. 251:226-235.

Delon, N., and Purves, D. 2018. Wild animal suffering is intractable. J. Agric. Environ. Ethics 31:239-260.

Dietz, A. 2018. Effective altruism and collective obligations. Utilitas 31: 106-115.

Dita, M., Barquero, M., Heck, D., Mizubuti, E. S., and Staver, C. P. 2018. Fusarium wilt of banana: Current knowledge on epidemiology and research needs toward sustainable disease management. Front. Plant Sci. 9: 1468 .

Douthwaite, B., and Hoffecker, E. 2017. Towards a complexity-aware theory of change for participatory research programs working within agricultural innovation systems. Agric. Syst. 155:88-102.

effectivealtruism.org. 2019. EA Concepts: Importance, tractability, neglectedness framework. The Centre for Effective Altruism. https://concepts. effectivealtruism.org/concepts/importance-neglectedness-tractability/

Embrey, S., Remais, J. V., and Hess, J. 2012. Climate change and ecosystem disruption: The health impacts of the North American Rocky Mountain pine beetle infestation. Am. J. Public Health 102:818-827.

Evenson, R. E., and Gollin, D. 2003. Assessing the impact of the Green Revolution, 1960 to 2000. Science 300:758-762.

Flood, J. 2010. The importance of plant health to food security. Food Secur. 2: $215-231$

Fortunato, S., Bergstrom, C. T., Börner, K., Evans, J. A., Helbing, D., Milojević, S., Petersen, A. M., Radicchi, F., Sinatra, R., Uzzi, B., and Vespignani, A. 2018. Science of science. Science 359:eaao0185.

Fox, A., Fowkes, A. R., Skelton, A., Harju, V., Kirk, A. B., Kelly, M., Forde, S. M. D., Pufal, H., Conyers, C., Ward, R., Weekes, R., Boonham, N., and Adams, I. P. 2019. Using high-throughput sequencing in support of a plant health outbreak reveals novel viruses in Ullucus tuberosus (Basellaceae). Plant Pathol. 68:576-587

Gabriel, I. 2017. Effective altruism and its critics. J. Appl. Philos. 34:457-473.

Garcia-Bastidas, F., Quintero-Vargas, C., Ayala-Vasquez, M., Seidl, M., Schermer, T., Santos-Paiva, M., Noguera, A. M., Aguilera-Galvez, C., Wittenberg, A., and Sørensen, A. 2020. First report of Fusarium wilt tropical race 4 in Cavendish bananas caused by Fusarium odoratissimum in Colombia. Plant Dis. 104:994.

Garrett, K. A. 2018. Impact network analysis: Evaluating the success of interventions. PeerJ Preprints 6:e27037v1.

Garrett, K. A., Alcalá-Briseño, R. I., Andersen, K. F., Buddenhagen, C. E., Choudhury, R. A., Fulton, J. C., Hernandez Nopsa, J. F., Poudel, R., and Xing, Y. 2018. Network analysis: A systems framework to address grand challenges in plant pathology. Annu. Rev. Phytopathol. 56:559-580.

Garrett, K. A., Andersen, K., Bowden, R. L., Forbes, G. A., Kulakow, P. A., and Zhou, B. 2017. Resistance genes in global crop breeding networks. Phytopathology 107:1268-1278.

Garrett, K. A., Forbes, G. A., Savary, S., Skelsey, P., Sparks, A. H., Valdivia, C., van Bruggen, A. H. C., Willocquet, L., Djurle, A., Duveiller, E., Eckersten, H., Pande, S., Cruz, C. V., and Yuen, J. 2011. Complexity in climate-change impacts: An analytical framework for effects mediated by plant disease. Plant Pathol. 60:15-30.

Gildemacher, P. R., Schulte-Geldermann, E., Borus, D., Demo, P., Kinyae, P., Mundia, P., and Struik, P. C. 2011. Seed potato quality improvement through positive selection by smallholder farmers in Kenya. Potato Res. 54: 253-266.

Graziosi, I., Tembo, M., Kuate, J., and Muchugi, A. 2020. Pests and diseases of trees in Africa: A growing continental emergency. Plants People Planet 2:14-28

Harari, Y. N. 2018. 21 Lessons for the 21st Century. Spiegel \& Grau, New York.

Hardin, G. 1968. The tragedy of the commons. Science 162:1243-1248.

Hardin, G. 1974. Commentary: Living on a LIFEBOAT. BioScience 24: 561-568.

Helfer, S. 2014. Rust fungi and global change. New Phytol. 201:770-780.

Herren, H. R., Neuenschwander, P., Hennessey, R. D., and Hammond, W. N. O. 1987. Introduction and dispersal of Epidinocarsis lopezi (Hym., Encyrtidae), an exotic parasitoid of the cassava mealybug, Phenacoccus manihoti (Hom., Pseudococcidae), in Africa. Agric. Ecosyst. Environ. 19:131-144.

Horsfall, J. G., and Cowling, E. B. 1978. Some epidemics man has known. Pages 17-32 in: Plant Disease An Advanced Treatise, Volume II: How Disease Develops in Populations. J. G. Horsfall and E. B. Cowling, eds. Academic Press, New York.

Huamán, Z., and Schmiediche, P. 1999. The potato genetic resources held in trust by the International Potato Center (CIP) in Peru. Potato Res. 42:413-426. 
Hughes, M. A., Smith, J., Ploetz, R., Kendra, P., Mayfield, A., Hanula, J., Hulcr, J., Stelinski, L., Cameron, S., and Riggins, J. 2015. Recovery plan for laurel wilt on redbay and other forest species caused by Raffaelea lauricola and disseminated by Xyleborus glabratus. Plant Health Prog. 16:173-210.

International Food Policy Research Institute. 2019. Global SpatiallyDisaggregated Crop Production Statistics Data for 2010, Version 1.0. Harvard Dataverse.

Koops, B.-J. 2015. The concepts, approaches, and applications of responsible innovation. Pages 1-15 in: Responsible Innovation 2: Concepts, Approaches, and Applications. B.-J. Koops, I. Oosterlaken, H. Romijn, T. Swierstra, and J. van den Hoven, eds. Springer International Publishing, Cham, Switzerland.

Levings, C. S. 1990. The Texas cytoplasm of maize: Cytoplasmic male sterility and disease susceptibility. Science 250:942-947.

Lizárraga, C., Santa Cruz, M., López, G., and Fuentes, S. 2001. Effect of viruses UMV, UVC, PapMV-U, and PLRV on Ulluco production and their control. Pages 381-389 in: Scientist and Farmer: Partners in Research for the 21st Century. Program Report 1999-2000. International Potato Center, ed. International Potato Center, Lima, Peru.

Lobell, D. B., Cassman, K. G., and Field, C. B. 2009. Crop yield gaps: Their importance, magnitudes, and causes. Annu. Rev. Environ. Resour. 34: 179-204.

Low, J., Ball, A., Magezi, S., Njoku, J., Mwanga, R., Andrade, M., Tomlins, K., Dove, R., and Van Mourik, T. 2017. Sweet potato development and delivery in sub-Saharan Africa. Afr. J. Food Agric. Nutr. Dev. 17:11955-11972.

MacAskill, W. 2015. Doing Good Better. Avery, New York, NY, U.S.A.

Mackenzie, D. 2007. Billions at risk from wheat super-blight. New Sci. 194: 6-7.

Mahmuti, M., West, J. S., Watts, J., Gladders, P., and Fitt, B. D. L. 2009. Controlling crop disease contributes to both food security and climate change mitigation. Int. J. Agric. Sustain. 7:189-202.

Margosian, M. L., Garrett, K. A., Hutchinson, J. M. S., and With, K. A. 2009. Connectivity of the American agricultural landscape: Assessing the national risk of crop pest and disease spread. Bioscience 59:141-151.

Mill, J. S., and Bentham, J. 1987. Utilitarianism and Other Essays. Penguin, New York.

Miranda, L. M., Bland, D. E., Cambron, S. E., Lyerly, J. H., Johnson, J., Buntin, G. D., and Murphy, J. P. 2010. Genetic mapping of an Aegilops tauschii-derived Hessian fly resistance gene in common wheat. Crop Sci. 50:612-616.

Monfreda, C., Ramankutty, N., and Foley, J. A. 2008. Farming the planet: 2. Geographic distribution of crop areas, yields, physiological types, and net primary production in the year 2000. Global Biogeochem. Cycles 22. doi: $10.1029 / 2007 \mathrm{~GB} 002947$

Mutiga, S., Hoffmann, V., Harvey, J., Milgroom, M., and Nelson, R. 2015. Assessment of aflatoxin and fumonisin contamination of maize in western Kenya. Phytopathology 105:1250-1261.

Myers, N., Mittermeier, R. A., Mittermeier, C. G., Da Fonseca, G. A., and Kent, J. 2000. Biodiversity hotspots for conservation priorities. Nature 403: 853-858.

Naylor, R. L., Falcon, W. P., Goodman, R. M., Jahn, M. M., Sengooba, T., Tefera, H., and Nelson, R. J. 2004. Biotechnology in the developing world: A case for increased investments in orphan crops. Food Policy 29: $15-44$.

Ndungo, V., Komi, F., and Mwangi, M. 2008. Banana Xanthomonas wilt in the DR Congo: Impact, spread and management. J. Appl. Biosci. 1:1-7.

Nelson, R. J., Naylor, R. L., and Jahn, M. M. 2004. The role of genomics research in improvement of "orphan" crops. Crop Sci. 44:1901-1904.

Ng, Y.-K. 1995. Towards welfare biology: Evolutionary economics of animal consciousness and suffering. Biol. Philos. 10:255-285.

$\mathrm{Ng}$, Y.-K. 2016. How welfare biology and commonsense may help to reduce animal suffering. Anim. Sentience 1:1-10.

Niblett, C. L., and Claflin, L. E. 1978. Corn lethal necrosis-a new virus disease of corn in Kansas. Plant Dis. Rep. 62:15-19.

Oliver, T. H., Heard, M. S., Isaac, N. J. B., Roy, D. B., Procter, D., Eigenbrod, F., Freckleton, R., Hector, A., Orme, D. L., Petchey, O. L., Proenca, V., Raffaelli, D., Suttle, K. B., Mace, G. M., Martin-Lopez, B., Woodcock, B. A., and Bullock, J. M. 2015. Biodiversity and resilience of ecosystem functions. Trends Ecol. Evol. 30:673-684.

Padmanabhan, S. Y. 1973. The Great Bengal Famine. Annu. Rev. Phytopathol. 11:11-24.

Pardey, P. G., Andrade, R. S., Hurley, T. M., Rao, X., and Liebenberg, F. G. 2016. Returns to food and agricultural R\&D investments in sub-Saharan Africa, 1975-2014. Food Policy 65:1-8

Ploetz, R. C., Hulcr, J., Wingfield, M. J., and De Beer, Z. W. 2013. Destructive tree diseases associated with ambrosia and bark beetles: Black swan events in tree pathology? Plant Dis. 97:856-872

Pummer, T. 2016. Whether and where to give. Philos. Public Aff. 44:77-95.
Raitzer, D. A., and Kelley, T. G. 2008. Benefit-cost meta-analysis of investment in the International Agricultural Research Centers of the CGIAR. Agric. Syst. 96:108-123.

Raudsepp-Hearne, C., Peterson, G. D., and Bennett, E. M. 2010. Ecosystem service bundles for analyzing tradeoffs in diverse landscapes. Proc. Natl. Acad. Sci. U.S.A. 107:5242-5247.

Redinbaugh, M. G., and Stewart, L. R. 2018. Maize lethal necrosis: An emerging, synergistic viral disease. Annu. Rev. Virol. 5:301-322.

Reeves, R. G., Voeneky, S., Caetano-Anollés, D., Beck, F., and Boëte, C. 2018. Agricultural research, or a new bioweapon system? Science 362:35-37.

Renkow, M., and Byerlee, D. 2010. The impacts of CGIAR research: A review of recent evidence. Food Policy 35:391-402.

Rittel, H. W. J., and Webber, M. M. 1973. Dilemmas in a general theory of planning. Policy Sci. 4:155-169.

Sandler, R. 2012. Intrinsic value, ecology, and conservation. Nat. Educ. Knowl. 3:4

Savary, S., Ficke, A., Aubertot, J.-N., and Hollier, C. 2012. Crop losses due to diseases and their implications for global food production losses and food security. Food Secur. 4:519-537.

Savary, S., Willocquet, L., Pethybridge, S. J., Esker, P., McRoberts, N., and Nelson, A. 2019. The global burden of pathogens and pests on major food crops. Nat. Ecol. Evol. 3:430-439.

Schmid, R. B., Knutson, A., Giles, K. L., and McCornack, B. P. 2018. Hessian fly (Diptera: Cecidomyiidae) biology and management in wheat. J. Integr. Pest Manage. 9:14.

Shiffrin, S. V. 1999. Wrongful life, procreative responsibility, and the significance of harm. Leg. Theory 5:117-148.

Silva-Rosales, L., Alcalá-Briseño, R. I., and Espejel, F. 2015. Sugarcane mosaic. Pages 131-143 in: Virus Diseases of Tropical and Subtropical Crops. P. Tennant and G. Fermin, eds. CABI, Wallingford, UK.

Singer, P. 2015. The Most Good You Can Do: How Effective Altruism is Changing Ideas About Living Ethically. Yale University Press, New Haven, CT.

Singh, D., Jackson, G., Hunter, D., Fullerton, R., Lebot, V., Taylor, M., Iosefa, T., Okpul, T., and Tyson, J. 2012. Taro leaf blight-A threat to food security. Agriculture 2:182-203

Singh, N., Wu, S., Tiwari, V., Sehgal, S., Raupp, J., Wilson, D., Abbasov, M., Gill, B., and Poland, J. 2019. Genomic analysis confirms population structure and identifies inter-lineage hybrids in Aegilops tauschii. Front. Plant Sci. 10:9.

Singh, R. P., Hodson, D. P., Jin, Y., Lagudah, E. S., Ayliffe, M. A., Bhavani, S., Rouse, M. N., Pretorius, Z. A., Szabo, L. J., and Huerta-Espino, J. 2015. Emergence and spread of new races of wheat stem rust fungus: Continued threat to food security and prospects of genetic control. Phytopathology $105: 872-884$

Soulé, M. E. 1985. What is Conservation Biology? A new synthetic discipline addresses the dynamics and problems of perturbed species, communities, and ecosystems. BioScience 35:727-734.

Stevenson, J. R., Villoria, N., Byerlee, D., Kelley, T., and Maredia, M. 2013. Green Revolution research saved an estimated 18 to 27 million hectares from being brought into agricultural production. Proc. Natl. Acad. Sci. U.S.A. $110: 8363-8368$.

Stilgoe, J., Owen, R., and Macnaghten, P. 2013. Developing a framework for responsible innovation. Res. Policy 42:1568-1580.

Stokes, D. E. 2011. Pasteur's Quadrant: Basic Science and Technological Innovation. Brookings Institution Press, Washington, DC.

Strange, R. N., and Scott, P. R. 2005. Plant disease: A threat to global food security. Annu. Rev. Phytopathol. 43:83-116.

Suffert, F., Latxague, É., and Sache, I. 2009. Plant pathogens as agroterrorist weapons: Assessment of the threat for European agriculture and forestry. Food Secur. 1:221-232.

Thomas-Sharma, S., Abdurahman, A., Ali, S., Andrade-Piedra, J. L., Bao, S., Charkowski, A. O., Crook, D., Kadian, M., Kromann, P., Struik, P. C., Torrance, L., Garrett, K. A., and Forbes, G. A. 2016. Seed degeneration in potato: The need for an integrated seed health strategy to mitigate the problem in developing countries. Plant Pathol. 65:3-16.

Unger, P. 1996. Living High and Letting Die: Our Illusion of Innocence. Oxford University Press, Inc., New York, NY, U.S.A.

Uyemoto, J. K. 1983. Biology and control of maize chlorotic mottle virus. Plant Dis. Rep. 67:7-10.

van Delden, S. H., Vos, J., Ennos, A. R., and Stomph, T. J. 2010. Analysing lodging of the panicle bearing cereal teff (Eragrostis tef). New Phytol. 186:696-707.

van der Burg, S., Bogaardt, M.-J., and Wolfert, S. 2019. Ethics of smart farming: Current questions and directions for responsible innovation towards the future. NJAS Wagening. J. Life Sci. 90-91:100289.

Varshney, R. K., Ribaut, J.-M., Buckler, E. S., Tuberosa, R., Rafalski, J. A., and Langridge, P. 2012. Can genomics boost productivity of orphan crops? Nat. Biotechnol. 30:1172-1176. 
Walker, B., Holling, C. S., Carpenter, S. R., and Kinzig, A. 2004. Resilience, adaptability and transformability in social-ecological systems. Ecol. Soc. 9:5.

Wangai, A. W., Redinbaugh, M. G., Kinyua, Z. M., Miano, D. W., Leley, P. K., Kasina, M., Mahuku, G., Scheets, K., and Jeffers, D. 2012. First report of Maize chlorotic mottle virus and maize lethal necrosis in Kenya. Plant Dis. 96:1582.

Wigboldus, S., Klerkx, L., Leeuwis, C., Schut, M., Muilerman, S., and Jochemsen, H. 2016. Systemic perspectives on scaling agricultural innovations. A review. Agron. Sustain. Dev. 36:46.

Willett, W., Rockström, J., Loken, B., Springmann, M., Lang, T., Vermeulen, S., Garnett, T., Tilman, D., DeClerck, F., Wood, A., Jonell, M., Clark, M., Gordon, L. J., Fanzo, J., Hawkes, C., Zurayk, R., Rivera, J. A., De Vries, W., Majele Sibanda, L., Afshin, A., Chaudhary, A., Herrero, M., Agustina, R., Branca, F., Lartey, A., Fan, S., Crona, B., Fox, E., Bignet, V., Troell, M., Lindahl, T., Singh, S., Cornell, S. E., Srinath Reddy, K., Narain, S., Nishtar, S., and Murray, C. J. L. 2019. Food in the Anthropocene: The EAT-Lancet
Commission on healthy diets from sustainable food systems. Lancet 393: 447-492.

Wilson, C. R. 2016. Plant pathogens-The great thieves of vegetable value. Acta Hortic. 1123:7-16.

Wolfert, S., Ge, L., Verdouw, C., and Bogaardt, M.-J. 2017. Big Data in smart farming-A review. Agric. Syst. 153:69-80.

Wyckhuys, K. A. G., Zhang, W., Prager, S. D., Kramer, D. B., Delaquis, E., Gonzales, C. E., and van der Werf, W. 2018. Biological control of an invasive pest eases pressures on global commodity markets. Environ. Res. Lett. 13:094005.

Xing, Y., Hernandez Nopsa, J., Andrade-Piedra, J., Beed, F., Blomme, G., Carvajal Yepes, M., Coyne, D., Forbes, G., Kreuze, J., Kroschel, J., Kumar, L., Legg, J., Parker, M., Schulte-Geldermann, E., and Garrett, K. A. 2017. Global cropland connectivity: A risk factor for invasion and saturation by emerging pathogens and pests. bioRxiv doi:10.1101/106542 